\title{
Cushing's Syndrome in Childhood: Postoperative Management
}

\author{
S. RAITI, * D. B. GRANT, D. INNES WILLIAMS, and G. H. NEWNS \\ From The Hospital for Sick Children, Great Ormond Street, London
}

\begin{abstract}
Raiti, S., Grant, D. B., Williams, D. I., and Newns, G. H. (1972). Archives of Disease in Childhood, 47, 597. Cushing's syndrome in childhood: postoperative management. Of 8 children with Cushing's syndrome, 7 had tumours and 1 bilateral adrenal hyperplasia. All had hypertension; 5 cases also showed virilization; only 3 had short stature. All excreted raised urinary $17 \mathrm{KS}$ and $17 \mathrm{OHCS}$. Pyelography showed displaced kidneys on the affected side in 5 cases.

Early postoperative complications occurred in 4 cases. 2 patients developed adrenal crisis. In 1 patient the blood pressure rose to very high levels but subsequently fell to normal. The fourth patient developed severe hypertension and acute pancreatitis and died.
\end{abstract}

One patient died from pneumonia $3 \frac{1}{2}$ years after operation.

A scheme for postoperative replacement therapy with cortisol is given.

Cushing's syndrome is uncommon in childhood. Hayles et al. (1966) collected 222 cases of adrenocortical secreting tumours from the literature and added 12 cases of their own. Klevit et al. (1966) collected 21 cases of Cushing's syndrome during the first year of life from the literature. Loridan and Senior (1969) described 3 infants and also a 13year-old child with Cushing's syndrome. We have treated 8 patients with Cushing's syndrome. Complications have arisen which were associated with postoperative hormonal management. This report describes these problems and the recommendations for treatment of such cases. The surgical management of adrenocortical tumours has been described previously (Williams, 1968).

\section{Case Reports}

The salient clinical and laboratory features are summarized in Tables I and II. All patients had the clinical features of Cushing's syndrome and virilization was also present in 5 patients. The cases are further described from the point of view of postoperative course. Before operation patients were given hydrocortisone in doses of $200 \mathrm{mg} /$ day (divided doses) for 2 days and $100 \mathrm{mg} 2$ hours immediately before the operation. An additional $50 \mathrm{mg}$ hydrocortisone was sometimes given during the operation, if indicated.

\footnotetext{
Received 16 December 1971.

$\star$ Present address: National Pituitary Agency, University of Maryland School of Medicine, Baltimore, Maryland, U.S.A.
}

Hydrocortisone $50 \mathrm{mg}$ at 6 - or 8-hour intervals was given after operation with the aim of keeping the total hydrocortisone dose during the day of operation at 200 to $300 \mathrm{mg}$.

Case 1: Cushing's syndrome with virilization and right hemihypertrophy. Body asymmetry had been noted at 6 months of age. At 3 years she underwent a laparotomy elsewhere because she was thought to have a gonadal tumour. Postoperatively, she developed wound infection and delayed wound healing.

After admission to this hospital, additional investigations were carried out. These included a dexamethasone test which showed no suppression of her urinary 17-ketosteroids (17KS) and 17-hydroxycorticoids (17OHCS). Her cortisol production rate was $57 \cdot 4$ $\mathrm{mg} / \mathrm{m}^{2}$ per 24 hours. A right adrenalectomy was performed. Because of the fear of recurrence of delayed wound healing, the hydrocortisone dose was reduced rapidly to 100,75 , and $50 \mathrm{mg}$ on successive postoperative days. On the fourth day, she underwent an Addisonian crisis but responded to appropriate therapy. The hydrocortisone dose was then reduced more cautiously from $200 \mathrm{mg} /$ day to $50 \mathrm{mg} /$ day (divided doses) over a 3-week period. This dose was subsequently reduced progressively and was stopped one year after operation. She had lost all cushingoid and virilizing features but her voice remained deep.

Case 2: Cushing's syndrome; renal calculi. In addition to the clinical features and other investigations as tabulated, this patient's intravenous pyelogram 
TABLE I

Clinical Features of 8 Cases of Cushing's Syndrome

\begin{tabular}{|c|c|c|c|c|c|c|c|}
\hline Case No. & Date of Birth & Sex & $\begin{array}{l}\text { Age at } \\
\text { Operation } \\
\text { (yr) }\end{array}$ & Presenting Features & $\begin{array}{l}\text { Height } \\
\text { (cm) }\end{array}$ & $\begin{array}{l}\text { Weight } \\
\text { (kg) }\end{array}$ & $\begin{array}{l}\text { Blood } \\
\text { Pressure } \\
\text { (mmHg) }\end{array}$ \\
\hline 1 & 4.12 .65 & $\mathbf{F}$ & $3 \frac{1}{2}$ & $\begin{array}{l}\text { Obesity; pubic hair; clitoral enlargement; vaginal } \\
\text { discharge; acne; deep voice for } 1 \frac{1}{2} \text { yr }\end{array}$ & $100 \cdot 5$ & $27 \cdot 0$ & $140 / 110$ \\
\hline $\begin{array}{l}2 \\
3\end{array}$ & $\begin{array}{l}6.8 .68 \\
29.3 .69\end{array}$ & $\begin{array}{l}\mathbf{M} \\
\mathbf{F}\end{array}$ & $\begin{array}{l}1 \\
10 / 12\end{array}$ & $\begin{array}{l}\text { Obesity and acne for } 3 / 12 \\
\text { Obesity for } 4 / 12\end{array}$ & $\begin{array}{l}74 \cdot 0 \\
63 \cdot 0\end{array}$ & $\begin{array}{l}12 \cdot 0 \\
10 \cdot 25\end{array}$ & $\begin{array}{l}150 / 110 \\
210 / 130\end{array}$ \\
\hline 4 & 30.4 .60 & $\mathbf{M}$ & $43 / 12$ & $\begin{array}{l}\text { Obesity; acne; hirsutism; facial and pubic hair; } \\
\text { moon face; striae for } 4 / 12\end{array}$ & $91 \cdot 5$ & $25 \cdot 5$ & $170 / 110$ \\
\hline $\begin{array}{l}5 \\
6\end{array}$ & $\begin{array}{l}3.7 .56 \\
27.7 .66\end{array}$ & $\begin{array}{l}\mathbf{F} \\
\mathbf{F}\end{array}$ & $\begin{array}{ll}1 & 2 / 12 \\
3 & 10 / 12\end{array}$ & $\begin{array}{l}\text { Obesity; acne; pubic hair; hirsutism for } 2 / 12 \\
\text { Obesity; hirsutism; facial, axillary, and pubic hair; } \\
\text { clitoral enlargement for } 3 \mathrm{yr}\end{array}$ & $\begin{array}{r}76 \cdot 0 \\
101 \cdot 0\end{array}$ & $\begin{array}{l}13 \cdot 0 \\
25 \cdot 4\end{array}$ & $\begin{array}{l}160 / 80 \\
150 / 110\end{array}$ \\
\hline 7 & 15.3 .58 & $\mathbf{M}$ & $13 / 12$ & $\begin{array}{l}\text { Obesity; abdominal mass; pubic and axillary hair } \\
\text { for } 4 / 12\end{array}$ & $63 \cdot 7$ & $10 \cdot 1$ & $160 / ?$ \\
\hline 8 & 14.2.55 & $\mathbf{M}$ & $103 / 12$ & Obesity for $3 / 12$ & $131 \cdot 0$ & $38 \cdot 5$ & $130 / 90$ \\
\hline
\end{tabular}

TABLE II

Investigations

\begin{tabular}{|c|c|c|c|c|c|c|c|c|c|}
\hline & \multirow{2}{*}{\multicolumn{2}{|c|}{ Bone Age $(y r)^{\star}$}} & \multirow{2}{*}{$\begin{array}{l}\text { Osteoporosis } \\
\frac{+}{-}\end{array}$} & \multirow{2}{*}{$\begin{array}{c}\text { IVP } \\
\text { (Displaced } \\
\text { Kidney) }\end{array}$} & \multirow{2}{*}{\multicolumn{2}{|c|}{$\begin{array}{c}\text { Urinary } \\
17 \mathrm{KS} \stackrel{17 \mathrm{OHCS}}{(\mathrm{mg} / 24 \mathrm{hr})}\end{array}$}} & \multirow{3}{*}{$\begin{array}{c}\begin{array}{c}\text { DHA } \\
\text { (mg/24 hr) }\end{array} \\
0 \cdot 7 \\
0 \cdot 5 \\
8 \cdot 0 \\
-\end{array}$} & \multicolumn{2}{|c|}{ Tumour } \\
\hline & & & & & & & & $\begin{array}{l}\text { Side } \\
\mathbf{R} \\
\mathbf{R} \\
\mathbf{R}\end{array}$ & $\begin{array}{l}\text { Size }(\mathrm{cm}) \\
5 \times 6 \times 3 \cdot 5 \\
5 \times 4 \times 2 \\
8 \times 5 \cdot 5 \times 3\end{array}$ \\
\hline $\begin{array}{l}1 \\
2 \\
3 \\
4 \\
5\end{array}$ & $\begin{array}{l}\frac{5}{6 / 12} \\
\text { Not measured } \\
1\end{array}$ & $\begin{array}{l}\frac{\left(3 \frac{1}{2}\right)}{(1)} \\
(12 / 12) \\
(310 / 12) \\
(13 / 12) \\
-\end{array}$ & $\begin{array}{l}+ \\
+ \\
+ \\
-\end{array}$ & $\begin{array}{c}+ \\
+ \\
+ \\
\text { Normal } \\
\text { Normal } \\
+ \\
+ \\
+\end{array}$ & $\begin{array}{r}10 \cdot 8 \\
8 \cdot 2 \\
40 \cdot 1 \\
5 \cdot 3 \\
3 \cdot 0 \\
156 \cdot 0 \\
4 \cdot 1 \\
10 \cdot 7\end{array}$ & $\begin{array}{r}12 \cdot 8 \\
9 \cdot 4 \\
11 \cdot 1 \\
42 \cdot 5 \\
21 \cdot 3\end{array}$ & & $\begin{array}{l}\mathbf{R} \\
\mathbf{R} \\
\mathbf{R} \\
\mathbf{R} \\
\mathbf{L} \\
\mathbf{R} \\
\mathbf{R} \\
\mathbf{L}\end{array}$ & $\begin{array}{l}5 \times 6 \times 3 \cdot 5 \\
5 \times 4 \times 2 \\
8 \times 5 \cdot 5 \times 3 \\
\quad- \\
\text { Not recorded } \\
3 \mathrm{~cm} \text { diameter } \\
16 \times 8.5 \times 5 \\
7 \times 5 \cdot 5 \times 4 \\
6 \times 4 \times 3\end{array}$ \\
\hline
\end{tabular}

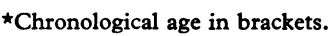

(IVP) showed 3 renal calculi in the left kidney. These had not produced symptoms or complications.

After operation, his hydrocortisone dose was reduced to 150 and $100 \mathrm{mg}$ /day (divided doses). On the fourth day he underwent an Addisonian crisis and was treated appropriately. His hydrocortisone dose was then reduced more cautiously over 7 postoperative weeks from $200 \mathrm{mg} /$ day to $22.5 \mathrm{mg} /$ day (divided doses). The dose was further reduced to $15 \mathrm{mg}$ and $10 \mathrm{mg} /$ day at 3 and 6 months and was then stopped. He lost his cushingoid features, and there were no other complications.

Case 3: Cushing's syndrome with severe hypertension. On admission this patient's blood pressure was $210 / 130 \mathrm{mmHg}$. 12 hours after the operation her blood pressure had risen to $250 / 160 \mathrm{mmHg}$, serum potassium had fallen to $2.8 \mathrm{mEq} / \mathrm{l}$., and her abdomen was distended. It was thought that these features were due partly to the preoperative hydrocortisone therapy (as outlined) and partly to excessive saltretaining hormones released by the tumour. Therefore, the dose of hydrocortisone was reduced rapidly to 150 and $100 \mathrm{mg} /$ day on the two subsequent days and then more slowly. No Addisonian symptoms occurred.
Her blood pressure remained raised at $200 / 120 \mathrm{mmHg}$ for 2 weeks and then fell progressively to $140 / 90 \mathrm{mmHg}$ by the sixth postoperative week. She was discharged during the seventh week on $30 \mathrm{mg} /$ day (divided doses) of hydrocortisone. After the third and sixth month, the hydrocortisone dose was reduced to 15 and $10 \mathrm{mg} /$ day and therapy was stopped after one year.

Case 4: Cushing's syndrome due to bilateral adrenal hyperplasia; hypertension; acute pancreatitis. This patient's IVP was normal. His cortisol production rate was $210 \mathrm{mg} / 24$ hours. A dexamethasone suppression test produced no change in his urinary $170 H C S$. Skeletal $x$-rays showed gross decalcification of his skull and some collapse of his thoracic vertebrae. Bone age was not determined. Bilateral total adrenalectomy was performed. The left and right adrenal glands weighed $8 \cdot 2$ and $8 \cdot 7 \mathrm{~g}$, respectively. Postoperatively, the patient was given hydrocortisone and also DOCA $2 \mathrm{mg}$ prophylactically. His blood pressure rose to $270 / 180 \mathrm{mmHg}$. Serpasil was given, and next day his blood pressure fell to 130 / $100 \mathrm{mmHg}$, followed by collapse requiring resuscitation. Abdominal paracentesis produced blood-stained fluid. He was re-explored but no haemorrhage was found, and 
he died. At necropsy acute pancreatitis was found. The adrenal histology showed bilateral adrenocortical hyperplasia with minimal nodularity.

Case 5: Cushing's syndrome due to multiple bilateral adrenocortical adenomata. The left adrenal gland was removed. The gland weighed $2 \cdot 5 \mathrm{~g}$. Histologically, multiple cortical adenomata were found. Postoperatively, the urinary 17-hydroxycorticoids remained raised, the levels ranging from 11 to 14 $\mathrm{mg} / 24$ hours. Two months later, a right adrenalectomy was performed. This adrenal gland weighed $3.5 \mathrm{~g}$, showed multiple cortical adenomata histologically, and its medulla was completely destroyed. The patient was subsequently followed at 6-month intervals. She developed convulsions $3 \frac{1}{2}$ years after operation and died soon afterwards. At necropsy, voluminous lungs were found from which an adenovirus was cultured. There were no abnormal findings elsewhere.

Case 6: Cushing's syndrome with virilization, mistaken for congenital adrenal hyperplasia. This patient developed pubic hair at 10 months. At $2 \frac{1}{2}$ years of age, she was thought to have congenital adrenal hyperplasia and was treated elsewhere with cortisone. Her urinary $17 \mathrm{KS}$ and $17 \mathrm{OHCS}$ were 5.0 and $4.8 \mathrm{mg} / 24$ hours. Neither pregnanetriol nor the 11-oxygenation index were measured.

She was referred because of progressive and uncontrolled virilization and the recent additional onset of cushingoid features. Preoperative diagnostic tests were carried out. At operation, a large adrenal tumour was found wrapped around the kidney which had to be removed with the tumour. Postoperatively, her hydrocortisone dose was reduced cautiously to $30 \mathrm{mg} /$ day (divided doses) by the end of the fifth week, and to 15 and $10 \mathrm{mg} /$ day at 3 and 6 months. To date, no postoperative complications have been found.

Case 7: Cushing's syndrome with virilization. At operation, the right adrenal gland with the tumour was removed. The left adrenal gland was noted to be very small. Postoperatively, the hydrocortisone dose was reduced cautiously and was stopped completely by the end of the eighth week. At this time, urinary $17 \mathrm{KS}$ and $17 \mathrm{OHCS}$ were 0.2 and $1.4 \mathrm{mg} / 24$ hours. After an ACTH stimulation test, urinary $17 \mathrm{OHCS}$ rose only to $2.3 \mathrm{mg} / 24$ hours. Hydrocortisone therapy was not reinstituted. $\mathrm{He}$ has been followed for 9 years, and there have been no complications.

Case 8. Cushing's syndrome. After operation the hydrocortisone dose was reduced cautiously and was stopped after 3 months. He has remained well during the subsequent 3 years.

\section{Discussion}

All 8 patients showed significant hypertension, and it could be postulated that their lesions produced both cortisol and salt-retaining hormones.
In addition, 5 patients had pubic hair and other virilizing features and their tumours probably also produced androgens. Males and females were equally affected. All patients were overweight (for height), the weight exceeding the 90 to 97 centile in all cases except one. Only 3 patients were below the 3rd centile in height. In 3 additional patients (who also were virilized), the heights were on the 75th and 50th centiles. A unilateral tumour was found in 6 cases, 3 of which had virilizing features. One case had bilateral adrenocortical hyperplasia; another had multiple bilateral adrenocortical adenomata, and both presented with virilizing and cushingoid features.

In the diagnostic tests performed before operation (Raiti, 1971), all patients had raised urinary 17KS and 17OHCS. DHA was found in the urine of the 4 cases so studied and was very high in 2 . The IVP showed a displaced kidney on the affected side in 5 of the 7 cases so studied, and all 5 had a unilateral tumour. The 6th and 7th cases had bilateral adrenal hyperplasia and bilateral tumours. Air insufflation was, therefore, rarely required. The dexamethasone suppression test (Wilkins, 1965) showed no alteration of the urinary $170 H C S$ excretion in the 2 patients so studied. This test has been used to differentiate adrenal tumours from bilateral hyperplasia and from simple obesity, but is not needed if a unilateral lesion can be shown by IVP. Moreover, this test does not always differentiate benign from malignant lesions (with or without metastases). Such metastases are recognized either at operation, or by radiological or other changes in other organs, or by showing histological infiltration of the tumour capsule, or by finding a rising urinary steroid excretion pattern postoperatively. The histological features of benign and malignant tumours are often very similar.

Postoperatively, 2 patients developed impending adrenal crises which were thought to be due to rapid reduction in hydrocortisone dose in patients whose tissues had become adjusted to high levels. These patients responded to therapy which included increased hydrocortisone dosage. The one patient (Case 3) with the highest preoperative blood pressure, developed both severer hypertension and electrolyte changes which were suggestive of excess salt-retaining hormone. It is possible that her tumour was secreting both cortisol and salt-retaining hormones. One patient (Case 4) was given DOCA after operation and he developed severe hypertension. Unless there are specific indications, it is not necessary to give prophylactic salt-retaining hormones routinely in addition to hydrocortisone to patients who have a unilateral adrenalectomy, 
because the secretion of aldosterone is controlled by the renin-angiotension mechanism from the kidney rather than by pituitary ACTH (Raiti et al., 1966, 1968). Delayed or disordered wound healing was not a feature of our patients. One patient developed acute pancreatitis and died. Another died from an unrelated pneumonia $3 \frac{1}{2}$ years after operation.

A small contralateral adrenal gland was seen in the 2 cases where this was looked for at operation, and one of these showed no response to ACTH stimulation 2 months later. Suppression of pituitary ACTH secretion is expected in patients with cortisol-secreting adrenal tumours, and this should result in a small contralateral gland. Such expected low plasma levels of ACTH and also of cortisol have been shown during the first few postoperative months, and complete recovery of both parameters only occurred after 9 months (Graber et al., 1965). In addition, the clinical features of adrenal insufficiency may resemble those found with the steroid withdrawal syndrome, which includes anorexia, nausea, lethargy, weight loss, and arthralgia. These symptoms may be due to conditioning of the body tissues to high levels of adrenal corticosteroids (Amatruda, Hurst, and D'Esopo, 1965).

In anticipation of such problems, patients should be given hydrocortisone in doses of $200 \mathrm{mg}$ /day for 2 days and also $100 \mathrm{mg} 2$ hours before surgery. Postoperatively, the patients should receive $50 \mathrm{mg}$ hydrocortisone every 6 hours for 3 days. These dose schedules appear to be adequate for most cases and overcome the dangers resulting either from higher dose levels or from too rapid withdrawal of hydrocortisone. Salt-retaining hormones need not be given unless specifically indicated. The total daily hydrocortisone dose should be reduced at 4-day intervals to $150,100,75,50$, and $30 \mathrm{mg}$. The patients can be discharged by the end of the third week on doses (divided) of 30 or $22.5 \mathrm{mg}$ hydrocortisone per day. This dose is further reduced at 3 and 6 months, and discontinued after 9 months.

Associated disorders include osteoporosis which was noted in 3 of our cases, one of which also had virilizing features. Such oesteoporosis usually affects the lower thoracic and lumbar vertebrae and was reported in $83 \%$ of cases (Plotz, Knowlton, and Ragan, 1952). It may persist for some months or years and no specific therapy is required (Soffer, Iannaccone, and Gabrilove, 1961). One of our affected patients has been followed for one year and has shown no complications. Hemihypertrophy was found in one of our patients, and this association has been reported previously (Gellis and Feingold, 1966; Copple and Duncan, 1966; Fraumeni and Miller, 1967). Another patient had renal calculi. Other disorders associated with adrenal tumours but not found in our patients have included congenital renal tract abnormalities, hamartomas, astrocytomas, congenital brain agenesis (Fraumeni and Miller, 1967), neuroblastoma (Kenny et al., 1967), renal ganglioneuroblastoma (Kogut and Donnell, 1961), nephrocalcinosis, duodenal ulcer, generalized oesteoporosis (Perlmutter et al., 1962), and mental deficiency (Sobel and Taft, 1959).

It is therefore recommended that special attention be given to the pre- and postoperative medical management of patients with adrenal tumours that secrete cortisol. Fewer such difficulties have been experienced with patients who have androgen secreting tumours of the adrenal gland and who present with virilizing but no cushingoid features.

\section{REFERENCES}

Amatruda, T. T., Jr., Hurst, M. M., and D'Esopo, N. D. (1965). Certain endocrine and metabolic facets of the steroid withdrawal syndrome. Fournal of Clinical Endocrinology and Metabolism, 25, 1207.

Copple, P. J., and Duncan, W. Y., III (1966). Congenital hemihypertrophy and adrenal carcinoma. American fournal of Diseases of Children, 111, 420.

Fraumeni, J. F., Jr., and Miller, R. W. (1967). Adrenocortical neoplasms with hemihypertrophy, brain tumors, and other disorders. Fournal of Pediatrics, 70, 129.

Gellis, S. S., and Feingold, M. (1966). Congenital hemihypertrophy and adrenal carcinoma. American Fournal of Diseases of Children, 111, 419.

Graber, A. L., Ney, R. L., Nicholson, W. E., Island, D. P., and Liddle, G. W. (1965). Natural history of pituitary-adrenal recovery following long-term suppression with corticosteroids. Fournal of Clinical Endocrinology and Metabolism, 25. 11.

Hayles, A. B., Hahn, H. B., Jr., Sprague, R. G., Bahn, R. C., and Priestley, J. T. (1966). Hormone-secreting tumors of the adrenal cortex in children. Pediatrics, 37, 19.

Kenny, F. M., Stavrides, A., Voorhess, M. L., and Klein, R. (1967). Cushing's syndrome associated with an adrenal neuroblastoma. American fournal of Diseases of Children, 113, 611.

Klevit, H. D., Campbell, R. A., Blair, H. R., and Bongiovanni, A. M. (1966). Cushing's syndrome with nodular adrenal hyperplasia in infancy. Fournal of Pediatrics, 68, 912.

Kogut, M. D., and Donnell, G. N. (1961). Cushing's syndrome in association with renal ganglioneuroblastoma. Pediatrics, 28, 566.

Loridan, L., and Senior, B. (1969). Cushing's syndrome in infancy. Fournal of Pediatrics, 75, 349.

Perlmutter, M., Apfel, A. Z., Avin, J., Hermann, H. B., and Klein, E. A. (1962). Cushing's syndrome in infancy: report of a case. Metabolism: Clinical and Experimental, 11, 946.

Plotz, C. M., Knowlton, A. I., and Ragan, C. (1952). The natural history of Cushing's syndrome. American fournal of Medicine, 13, 597.

Raiti, S. (1971). Assessment of endocrine function. In Recent Advances in Paediatrics, 4th ed., p. 245 . Ed. by D. Gairdner and D. Hull. Churchill, London.

Raiti, S., Kowarski, A., Morris, R. E., Jr., and Migeon, C. J. (1966). Some aspects of the control of aldosterone secretion in man. fohns Hopkins Hospital Bulletin, 119, 407.

Raiti, S., Kowarski, A., Weldon, V. V., and Migeon, C. J. (1968). Secretion of cortisol, corticosterone and aldosterone in children with hypopituitarism. fohns Hopkins Medical fournal, 122, 229. 
Sobel, E. H., and Taft, L. T. (1959). Cushing's syndrome and suspected mental retardation in an 18-month-old boy. Pediatrics, 23, 413.

Soffer, L. J., Iannaccone, A., and Gabrilove, J. L. (1961). Cushing's syndrome: a study of fifty patients. American fournal of Medicine, 30, 129.

Wilkins, L. (1965). The Diagnosis and Treatment of Endocrine Disorders in Childhood and Adolescence, 3rd ed., p. 359 . Thomas, Springfield, Illinois.
Williams, D. I. (1968). Paediatric Urology, p. 427. Butterworths, London.

Correspondence to Dr. S. Raiti, National Pituitary Agency, Suite 503-7, 210 West Fayette Street, Baltimore, Maryland 21201, U.S.A. 